\title{
Species Identification by Means of Mitochondrial Cytochrome $b$ DNA Sequencing in Processed Anchovy, Sardine and Tuna Products
}

\author{
Anna Cutarelli, Giorgio Galiero, Federico Capuano, Federica Corrado* \\ Istituto Zooprofilattico Sperimentale del Mezzogiorno, Napoli, Italy \\ Email: ^federica.corrado@cert.izsmportici.it
}

How to cite this paper: Cutarelli, A., Galiero, G., Capuano, F. and Corrado, F. (2018) Species Identification by Means of Mitochondrial Cytochrome $b$ DNA Sequencing in Processed Anchovy, Sardine and Tuna Products. Food and Nutrition Sciences, 9, 369-375.

https://doi.org/10.4236/fns.2018.94029

Received: March 6, 2018

Accepted: April 27, 2018

Published: April 30, 2018

Copyright $\odot 2018$ by authors and Scientific Research Publishing Inc. This work is licensed under the Creative Commons Attribution International License (CC BY 4.0).

http://creativecommons.org/licenses/by/4.0/

\section{(c) (i) Open Access}

\begin{abstract}
Identifying the contents of processed food products is essential to correct labelling. In processed foodstuffs, species identification through morphological analysis is difficult. Several factors hinder the identification of fish species in processed foods: proteins or other materials subjected to analysis may be denatured during heat treatments; the presence of other ingredients (e.g., olive and other vegetable oils) may interfere with the analysis. Consequently, possible frauds perpetrated by replacing valuable species with less precious ones may go undetected. In most processed samples (e.g. canned products), DNA is degraded into small fragments, which considerably reduces the sensitivity of molecular analysis. The main goal of our research was to develop an analytical method able to identify fish species in highly processed products, such as canned fish. The assay was developed by combining an effective method of DNA recovery from samples with the detection of small-sized sequences of the mitochondrial $C y t b$ gene. This method appears particularly suitable when morphological characterization is difficult, to carry out such as in canned products where DNA is degraded or present in small quantities. We have analyzed 60 samples of seafood commercial products identifying 3 different genera and five different species. All analyzed samples revealed a correct species declaration, for one sample we highlighted important commercial fraud. We also used bio-informatic identification systems for the Sequence Alignment and the construction of phylogenetic tree to better confirm the revealed fraud.
\end{abstract}

\section{Keywords}

Species Identification, Processed Seafood, Commercial Fraud, Dna Sequencing, Cytochrome $b(C y t b)$ 


\section{Introduction}

It is important to identify the fish species used in commercial products, in order to unmask possible frauds, which may be perpetrated by replacing valuable species with others of lower value or protected species, especially in elaborately processed foodstuffs (fish in oil and canned products) [1]. Precautionary measures are necessary, especially since substituted or mislabeled fish may contain unknown toxic or allergenic substances that are potentially dangerous [2]. For this reason, the demand for analytical tests by the authorities responsible for food monitoring is increasing worldwide [3]. Forensic genetic techniques for species identification provide an essential tool for the authentication of seafood in the marketplace, and should be more widely applied in order to maintain the credibility of certification by discouraging commercial fraud [4]. While whole fish can easily be identified on the basis of morphology, according to dichotomous keys proposed by the FAO, processed products can be more difficult to identify. In order to solve this problem, several molecular assays based on the analysis of polymorphic DNA sequences of the mitochondrial genome (DNA barcoding) have been developed in recent years. DNA barcoding is used for the rapid and accurate identification of animal or plant species not listed on the labels of processed foods [5].

The aim of our study was to develop and validate a sensitive and specific method of identifying fish species products highly processed and might have been heated to temperature $>100^{\circ} \mathrm{C}$ to cook or sterilize them. This resulted in DNA degradation and so PCR primers were used to amplify fragments of $200 \mathrm{bp}$ or less [6]. The assay developed was then carried out on 60 processed seafood products sold in Italy, with the aim of identifying the fish species utilized by means of DNA barcodes and comparing our data with the species listed on the product labels.

Nowadays, people tend to spend less time preparing food; consequently, the consumption of processed foods has risen. The present study was designed to provide a suitable, inexpensive tool for ensuring the authenticity and origin of fish in canned fish preparations. As genetic markers, we chose the Cytb gene, since these mitochondrial DNA (mtDNA) sequences are the most widely used markers for fish species identification [7]-[12]. The mtDNA analyze sequence derived from the gene encoding cytochrome $b$, used for the purpose of species identification by PCR because mtDNA is multicopy DNA existing in every cell. Furthermore, the mtDNA of most animals evolves more rapidly than nuclear DNA, and often shows higher levels of intra-specific polymorphism and population subdivision [7].

Species to be submitted to mitochondrial DNA barcoding were selected according to their consumption in Italy and their commercial value.

\section{Materials and Methods}

\subsection{Sample Collection}

Samples of canned fish were delivered to our laboratory by Health authorities as 
in PIF (Border Inspection Posts), NAS (Military Health Authority) and ASL (Local Health Authority). We carried out our analysis on 60 samples of commercial seafood (Table 1).

\subsection{DNA Extraction and PCR}

DNA was extracted from $200 \mathrm{mg}$ of each processed fish sample by means of the Nucleospin ${ }^{\circledR}$ Food kit (Macherey-Nagel GmbH \& Co., Düren, Germany). The sample was first placed over night in twice-distilled water to remove the oil, and then centrifuged at 13,000 rpm for 10 minutes. The supernatant was removed, and the pellet used for DNA recovery. The pretreatment of the samples improves the quality of extracted DNA. The quantity and quality of DNA extracted was evaluated using the A260/A280 ratio. Our samples had a values between 1.8 and 2 indicate a good DNA extract with little protein contaminants [13].

\subsection{PCR Assay}

For the PCR-based assay, a region of 577 bp was the selected target this was amplified by means of the primers: Tuna For, 5'-CAGGACTATTCCTCGCAATACA-3', and Tuna Rev, 5'-CGAAACAAGGAGGTCTTTGTA-3' [7].

The PCR reaction mix $(50 \mu \mathrm{L})$ consisted of: $25 \mu \mathrm{L}$ HotStar Taq ${ }^{\oplus}$ Master mix (Qiagen $\mathrm{GmbH}$, Hiden, Germany), $1 \mu \mathrm{L}$ of each primer $(10 \mu \mathrm{M}), 18 \mu \mathrm{L}$ RNAse/DNAse-free water and $100 \mathrm{ng}$ of DNA. The thermal profile for Tuna F/R primers was the following: a first step of $15 \mathrm{~min}$ at $95^{\circ} \mathrm{C}, 30$ cycles of $1 \mathrm{~min}$ at $95^{\circ} \mathrm{C}, 1 \mathrm{~min}$ at $52^{\circ} \mathrm{C}$, and $1 \mathrm{~min}$ at $68^{\circ} \mathrm{C}$, and a final elongation step of $5 \mathrm{~min}$ at $68^{\circ} \mathrm{C}$. For PCR amplification in anchovy and sardine samples, a segment of 376 base pairs of mitochondrial cytochrome $b$ was amplified by means of the primers: L14841 5'-AAAAAGCTCCAACATCTCAGCATGATGAAA-3' and H15149 5'AAACTGCACCCTCAGAATGATATTTGTCCTCA-3' [8]. The PCR reaction mix $(50 \mu \mathrm{L})$ consisted of: $25 \mu \mathrm{L}$ HotStar Taq ${ }^{\circledast}$ Master mix (Qiagen GmbH, Hiden, Germany), $1 \mu \mathrm{L}$ of each primer $(10 \mu \mathrm{M}), 18 \mu \mathrm{L}$ RNAse/DNAse-free water

Table 1. Identified species of commercial seafood products analyzed by $C y t b$ sequencing (3 genera and 5 species).

\begin{tabular}{ccc}
\hline Processed fish product & Declared species & Identified species \\
Tuna in Oil & Thunnus alalunga & Thunnus thynnus \\
Tuna in Oil & Thunnus albacares & Thunnus albacares \\
Tuna in Oil & Thunnus obesus & Thunnus obesus \\
Tuna in Oil & Thunnus thynnus & Thunnus thynnus \\
Anchovy in Oil & Engraulis encrasicolus & Engraulis encrasicolus \\
Marinated Anchovies & Engraulis encrasicolus & Engraulis encrasicolus \\
Sardina in oil & Sardina pilchardus & Sardina pilchardus
\end{tabular}


first step of $15 \mathrm{~min}$ at $95^{\circ} \mathrm{C}, 35 \mathrm{cycles}$ of $30 \mathrm{sec}$ at $95^{\circ} \mathrm{C}, 30 \mathrm{sec}$ at $52^{\circ} \mathrm{C}$, and $1 \mathrm{~min}$ and $100 \mathrm{ng}$ of DNA. The thermal profile for $\mathrm{L} / \mathrm{H}$ primers was the following: a at $72^{\circ} \mathrm{C}$, and a final elongation step of $7 \mathrm{~min}$ at $72^{\circ} \mathrm{C}$. Amplified PCR products were visualized on a QIAxcel ${ }^{\circledR}$ System and then sequenced.

\subsection{DNA Sequencing}

PCR products were purified by means of a Qiaquick $^{\circledast}$ PCR purification Kit (Qiagen GmbH, Hiden, Germany) and bi-directionally PCR sequenced with a BigDye $^{\circledast}$ Terminator v1.1 Cycle Sequencing Kit (Applied Biosystems, Foster City, California) following the manufacturer's recommendations. Sequences were dye-terminator removed by means of a DyeEx ${ }^{\circledast} 2.0$ spin kit (Qiagen $\mathrm{GmbH}$, Hiden, Germany) and the nucleotide sequence of the amplicon was then detected by means of a 3130 Genetic Analyzer (Thermo Fisher, Foster City, California). Electropherograms were analysed by means of Sequencing analysis v 5.2 and sequence scanner v1.0 software (Thermo Fisher, Foster City, California). The sequences obtained from the $C y t b$ gene were treated by deleting regions of low quality and rectifying ambiguities, and were identified by means of the Basic Local Alignment Search Tool (BLAST www.ncbi.nlm.nih.gov/blast). For phylogenetic analysis, two free programs, BioEdit and MEGA5 [14] were used (Figure 1).

\section{Results}

The 60 samples of canned fish analyzed proved to belong to 3 genera and 5 species (Table 1). As reported in Table 1, identification through DNA barcoding allowed us to characterize all the samples analyzed. The DNA extracted from all the samples proved to be of good quality and allowed optimal sequence analysis. We were able to detect the species in all the samples (Table 1).

The species declared on the label was confirmed in all samples except two, which was labeled as Thunnus alalunga instead of Thunnus thynnus, as proved by our assays. All other samples were correctly labeled as Thunnus albacares, Thunnus obesus, Sardina pilchardus and Engraulis encrasicolus.

\section{Discussion}

This study was carried out in order to validate a sensitive and specific method of identifying fish species on the basis of direct sequencing of two specific targets of the mitochondrial gene $C y t b$.

The analysis was performed by sequencing two several fragment of cytochrome $b$ gene, so the mtDNA method based on the sequencing of two fragment of cytochrome $\mathrm{b}$ gene allow good identification respectively for specie Tuna and species Sardine and anchovy [7] [8]. The assay was tested on 60 canned seafood products and fish in oil sold in Italy. The study showed that the preserving conditions (salt-curing, cooking or filleting and packaging in oil) did not affect the quality of the mtDNA. 

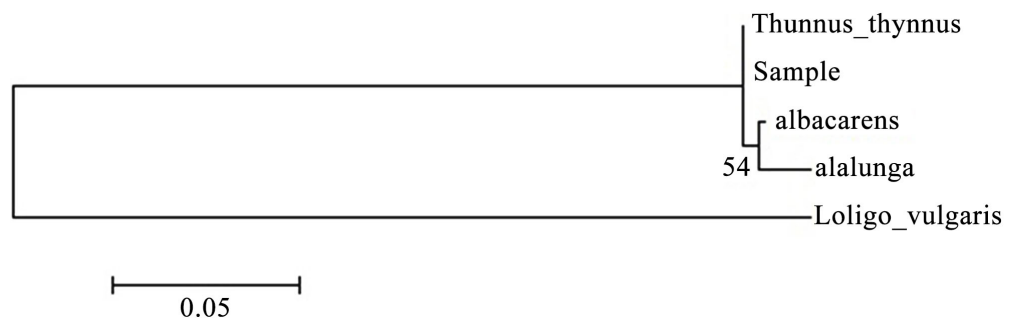

Figure 1. Neighnbor-joining tree based on partial $C y t b$ gene showing phylogenetic similarity among sample of Tuna in oil and reference sequence (Blast system) of Thunnus thunnus, Thunnus albares and Thunnus alalunga. The Loligo vulgaris Cytb gene (EF423061.1) was used as an outgroup. Numbers at the nodes indicate the bootstrap confidence values obtained after 1000 replications.

The exceptional biodiversity of marine fauna raises the possibility of finding alien species that cannot easily be identified through morphological analysis, especially if they are sold as fillets or slices [15]. Our results indicated that each of the species examined showed a unique and clearly distinguishable sequence. This finding also demonstrates that DNA barcoding is feasible and that the $C y t b$ mitochondrial sequence can be successfully used to identify commonly marketed processed seafood products. Indeed, two standard $C y t b$ sequence barcode regions, around $577 \mathrm{bp}$ and $376 \mathrm{bp}$, are relatively well conserved within a given species at the same time, however, they show sufficient variation to allow differentiation between species [16]. The correct and reliable identification of species is of particular importance in processed foodstuffs, since processing often obliterates or alters morphological characteristics [5]. In these cases, identification by means of conventional taxonomic features becomes very difficult or impossible. As reported in the literature [16], long fragments are difficult to recover from heavily processed foodstuffs. Nevertheless, we were able to identify the species in all the processed food samples analyzed. Fish species processed by means of breading and cooking have been identified through molecular assays. None of these technological processes have proved to impair DNA quality and subsequent sequencing analysis. Application of the protocol described above enabled us to confirm that the great majority of the samples analyzed had been correctly labeled it also revealed a species substitution fraud in a sample sold as tuna in oil (reported in the first row in Table 1). This sample was labeled as Alalunga Tuna (Thunnus alalunga) instead of Red Tuna (Thunnus thynnus). This mislabeling was probably intended to mask the use of Thunnus thynnus caught illegally in contravention of the restrictions imposed by current Italian legislation [17].

\section{Conclusions}

In agreement with our previous research, this study confirmed that molecular methods involving DNA sequencing can be successfully used to increase the traceability of food products, particularly with regard to the trade and processing 
of seafood [18]. This valuation is in accordance with Resolution No. 2016/2532 (RSP) of the European Parliament concerning the traceability of fishery products.

In conclusion, DNA sequencing is one of the most powerful tools for identifying fish species and promoting food safety and sustainable fisheries. Given that the consumption of ready-to-eat seafood products and take-away meals is constantly growing (http://www.ismea.it) [19], this technique should be urgently applied. It is necessary to have an easy and accurate method for the rapid analysis of highly processed products, such as seafood that is canned or preserved in oil. Indeed, the fraud revealed by our study reflects the potential increase in commercial frauds involving seafood products.

\section{References}

[1] Galimberti, A., De Mattia, F., Losa, A., Bruni, I., Federici, S., Casiraghi, M., Martellos, S. and Labra, M., (2013) DNA Barcoding as a New Tool for Food Traceability. Food Research International, 50, 55-63. https://doi.org/10.1016/j.foodres.2012.09.036

[2] Barbuto, M., Galimberti, A., Ferri, E., Labra, M., Malandra, R., Galli, P. and Casiraghi, M. (2010) DNA Barcoding Reveals Fraudulent Substitutions in Shark Seafood Products: The Italian Case of "Palombo" (Mustelus spp.). Food Research International, 43, 376-381. https://doi.org/10.1016/j.foodres.2009.10.009

[3] FAO (2016) The State of World Fisheries and Aquaculture 2016. Contributing to Food Security and Nutrition for All. Rome, 200 p.

[4] Cline, E. (2012) Marketplace Substitution of Atlantic Salmon for Pacific Salmon in Washington State Detected by DNA Barcoding. Food Research International, 45, 388-393. https://doi.org/10.1016/j.foodres.2011.10.043

[5] Handy, S.M., Deeds, J.R., Ivanova, N.V., Hebert, P.D., Hanner, R.H., Ormos, A., Weigt, L.A., Moore, M.M. and Yancy, H.F. (2011) A Single-Laboratory Validated Method for the Generation of DNA Barcodes for the Identification of Fish for Regulatory Compliance. Journal of AOAC International, 94, 201-210.

[6] Hajibabaei, M., Smith, M.A., Janzen, D.H., Rodriguez, J.J., Whitfield, J.B. and Hebert, P.D.N. (2006) A Minimalist Barcode Can Identify a Specimen Whose DNA Is Degraded. Molecular Ecology, 6, 959-964. https://doi.org/10.1111/j.1471-8286.2006.01470.x

[7] Michelini, E., Cevenini, L., Mezzanotte, L., Simoni, P., Baraldini, M., et al. (2007) One-Step Triplex-Polymerase Chain Reaction Assay for the Authentication of Yellowfin (Thunnus albacares), Bigeye (Thunnus obesus), and Skipjack (Katsuwonus pelamis) Tuna DNA from Fresh, Frozen, and Canned Tuna Samples. Journal of Agricultural and Food Chemistry, 55, 7638-7647. https://doi.org/10.1021/jf070902k

[8] Sebastio, P., Zanelli, P. and Neri, T.M. (2001) Identification of Anchovy (Engraulis encrasicholus L.) and Gilt Sardine (Sardinella aurita) by Polymerase Chain Reaction, Sequence of Their Mitochondrial Cytochrome b Gene, and Restriction Analysis of Polymerase Chain Reaction Products in Semipreserves. Journal of Agricultural and Food Chemistry, 49, 1194-1199. https://doi.org/10.1021/jf000875x

[9] Kochzius, M., Seidel, C., Antoniou, A., Kumar Botla, S., Campo, D., et al. (2010) Identifying Fishes through DNA Barcodes and Microarrays. PLoS ONE, 5, 12620. https://doi.org/10.1371/journal.pone.0012620 
[10] Lakra, W.S., Verma, M.S., Goswami, M., Lal, K.K., Mohindra, V., et al. (2011) DNA Barcoding Indian Marine Fishes. Molecular Ecology Resources, 11, 60-71. https://doi.org/10.1111/j.1755-0998.2010.02894.x

[11] Steinke, D., Vences, M., Salzburger, W. and Meyer, A. (2005) TaxI: A Software Tool for DNA Barcoding Using Distance Methods. Philosophical Transactions of the Royal Society B, 360, 1975-1980. https://doi.org/10.1098/rstb.2005.1729

[12] Hubert, N., Hanner, R., Holm, E., Mandrak, N.E., Taylor, E., et al. (2008) Identifying Canadian Freshwater Fishes through DNA Barcodes. PLoS ONE, 3, e2490. https://doi.org/10.1371/journal.pone.0002490

[13] Chapela, M.J., Sánchez, A., Suárez, M.I., Pérez-Martín, R.I. and Sotelo, C.G. (2007) A Rapid Methodology for Screening Hake Species (Merluccius spp.) by Single-Stranded Conformation Polymorphism Analysis. Journal of Agricultural and Food Chemistry, 55, 6903-6909.

[14] Tamura, K., Nei, M. and Kumar, S. (2004) Prospects for Inferring Very Large Phylogenies by Using the Neighbor-Joining Method. Proceedings of the National Academy of Sciences (USA), 101, 11030-11035.

https://doi.org/10.1073/pnas.0404206101

[15] Galil, B.S. (2007) Loss or Gain? Invasive Aliens and Biodiversity in the Mediterranean Sea. Marine Pollution Bulletin, 55, 314-322.

https://doi.org/10.1016/j.marpolbul.2006.11.008

[16] Rasmussen Hellberg, R.S. and Morrissey, M.T. (2011) Advance in DNA-Based Techniques for the Detection of Seafood Species Substitution on the Commercial Market. Technology Review JALA, 16, 308-321.

[17] Decreto Direttoriale n. 4961 del 14 marzo 2016: Disposizioni applicative tonno rosso 2016.

[18] Filonzi, L., Chiesa, S., Vaghi, M. and Nonnis Marzano, F. (2010) Molecular Barcoding Reveals Mislabelling of Commercial Fish Products in Italy. Food Research International, 43, 1383-1388. https://doi.org/10.1016/j.foodres.2010.04.016

[19] Ismea. Il consumo extradomestico di prodotti ittici-Marzo 2013. http://www.ismea.it/flex/cm/pages/ServeBLOB.php/L/IT/IDPagina/8846 